\title{
MENINGKATKAN HASIL BELAJAR MATERI MALAIKAT DAN TUGASNYA MENGGUNAKAN MEDIA POSTEROID SISWA SEKOLAH DASAR
}

\author{
Istiqomah \\ SD Negeri 25 Sungai Kakap \\ Email:istiqomah_123@gmail.com
}

\begin{abstract}
Abstrak
Pendidikan Agama Islam adalah salah satu mata pelajaran yang sangat penting. Namun di SD Negeri 25 Sungai Kakap, khususnya di Kelas IV hasil belajar siswa masih belum mencapai KKM. Hal ini disebabkan oleh faktor kurangnya variasi dalam pembelajaran. Berdasarkan hal ini, maka dilakukan Penelitian Tindakan Kelas untuk memperbaiki proses dan mutu pembelajaran dengan menggunakan media Posteroid. Media Posteroid adalah media poster yang dibuat dengan menggunakan aplikasi yang dapat diunduh dan dibuat melalui android. Subjek penelitian ini adalah siswa kelas IV SD Negeri 25 Sungai Kakap. Penelitian ini dilakukan 3 siklus, setiap siklus terdiri dari 4 tahap yaitu perencanaan, pelaksanaan, pengamatan dan refleksi. Hasil penelitian menunjukkan terjadi peningkatan hasil belajar siswa dengan menggunakan media Posteroid yaitu pada pra siklus nilai rata-rata sebesar 58,61, pada siklus I nilai rata-rata sebesar 61,11, siklus II nilai rata-rata sebesar 72,5 dengan persentase ketuntasan 50\% dan pada siklus III nilai rata-rata sebesar 94,44 dengan persentase ketuntasan sebesar $100 \%$.
\end{abstract}

\section{Kata Kunci: Hasil Belajar, Pelajaran PAI, Media Posteroid}

\section{PENDAHULUAN}

Salah satu hal penting yang harus dilakukan setiap manusia adalah pendidikan. Melalui pendidikan maka manusia akan mendapat pengetahuan serta pengetahuan yang luas untuk meningkatkan martabat dalam kehidupan. Pendidikan yang diperlukan tentunya yang sesuai dengan perkembangan manusia. Tentunya disini yang akan di fouskan adalah pendidikan pada jenjang Sekolah Dasar, karena pada setiap usia sekolah akan memiliki karakteristik dan kebutuhan yang berbeda, (Sumantri,2011:29).

Pendidikan ini diperoleh melalui proses dari pendidikan dasar, menengah, sampai perguruan tinggi. Pengetahuan yang diperoleh melalui pendidikan akan sangat berguna bagi masa depan, ketika seseorang mampu mengaplikasikan pengetahuannya secara secara maksimal. Manusia harus menyadari dan memahami bahwa pendidikan yang didapat bukanlah sekadar formalitas belaka. Namun lebih dari itu, pendidikan akan sangat menentukan kehidupan berbangsa dan bernegara yang harus dilatih dan dikembangkan sejak usia dini.

Dalam pembelajaran Pendidikan Agama Islam, keaktifan siswa dalam proses pembelajaran sangat diharapkan serta sangat penting. Namun pada kenyataannya, dilapangan pendidik masih menggunakan metode konvensional yaitu lebih banyak berceramah dan menginstruksikan siswa untuk mencatat. Metode ceramah dapat dikategorikan metode tradisional, karena sejak dulu metode selalu dipergunakan guru dalam proses pembelajaran. Metode ceramah merupakan metode yang menjamur ketika diterapkan dalam proses pembelajaran. dengan metode ini, mengakibatkan pembelajaran yang dilaksanakan menjadi berfokus pada guru, siswa menjadi pasif dan tidak aktif dalam pembelajarannya. Pembelajaran disekolah juga lebih menuntut pada kemampuan menghafal siswa tanpa memperhatikan dari kemampuan afektif dan psikomotornya.

Salah satu cara untuk meningkatkan hasil belajar siswa adalah menciptakan media-media pembelajaran yang inovatif yang mampu mempermudah siswa memahami materi pelajaran yang disampaikan serta meningkatkan motivasi siswa. Inovasi merupakan suatu upaya sadar yang sengaja dilakukan untuk memperbaiki prakti pendidikan, (Puji,2014:38). Pendidik harus berlaku secara profesional dengan memiliki berbagai kemampuan yang nantinya dapat divariasikan dengan model pembelajaran yang sesuai. Model pembelajaran adalah pola yang 
digunakan sebagai pedoman dalam merencanakan pembelajaran di kelas. Sangat penting bagi pendidik untuk menerapkan model pembelajaran yang bervariasi maupun menggunakan media pembelajaran inovatif yang menarik sehingga pembelajaran bisa beralih atau berfokus pada siswa.

Pembelajaran kooperatif adalah pendekatan pembelajaran yang berfokus pada penggunaan kelas kecil siswa untuk bekerja sama dalam memaksimalkan kondisi belajar untuk mencapai tujuan belajar. Model pembelajaran kooperatif dapat digunakan dengan memvariasikan media pembelajaran menarik yang mampu membantu guru menyampaikan materi pelajaran dan mampu memotivasi siswa untuk berperan aktif tanpa keterpaksaan namun dijalani dengan hati dan perasaan yang menyenangkan.

Berdasarkan hasil pengamatan peneliti di SD Negeri 25 Sungai Kakap terhadap pembelajaran Agama Islam yang belum optimal. Siswa hanya mendengarkan dan mencatat penjelasan dari guru. Siswa cenderung pasif, meskipun ada materi yang belum jelas baginya. Hal itu terjadi karena sebagian siswa tidak memperhatikan saat pembelajaran siswa sibuk dengan kegiatannya sendiri, berbicara dan bermain. Pembelajaran masih berfokus pada guru. Guru juga belum menerapkan berbagai model pembelajaran. Alasan utamanya karena dengan metode konvensional yang biasa digunakan oleh guru selama ini, akan mempermudah dalam proses pembelajaran.

Penerapan pembelajaran kooperatif menggunakan media posteroid akan mampu membuat siswa aktif dalam pembelajaran sehingga membuat pembelajaran lebih bermakna karena adanya keterlibatan siswa secara aktif selama proses pembelajaran berlangsung. Siswa akan terlibat dalam kegiatan pembelajaran dan guru sebagai fasilitator. Siswa juga akan terlatih untuk mengungkapkan gagasan, pendapat dan kritikan terhadap orang lain. Sehingga diharapkan mampu meningkatkan hasil belajar siswa.

\section{METODE PENELITIAN}

Penelitian ini adalah tindakan kelas (action research) karena bertujuan untuk memecahkan permasalahan dikelas atau bertujuan untuk memperbaiki proses pembelajaran yang pada akhirnya dapat meningkatkan hasil belajar siswa. Subjek penelitian pada penelitian ini adalah SD Negeri 25 Sungai Kakap Kabupaten Kubu Raya. Objek penelitian tindakan kelas ini adalah siswa kelas IV yang berjumlah 18 orang siswa terdiri dari 10 siswa laki-laki dan 8 siswa perempuan.

Penelitian ini akan dilaksanakan pada bulan Maret sampai dengan April 2018. Tempat penelitian tindakan kelas ini dilaksanakan di SD Negeri 25 Sungai Kakap yang beralamat di Parit Bujur Desa Sungai Itik Kecamatan Sungai Kakap Kabupaten Kubu Raya untuk mata pelajaran Pendidikan Agama Islam kelas IV. Dan peneliti mengambil objek pada kelas IV yang berjumlah 18 orang terdiri dari 10 siswa laki-laki dan 8 siswa perempuan. Penelitian tindakan kelas dirancang dalam tiga siklus untuk melihat peningkatan hasil belajar siswa pada mata pelajaran Pendidikan agama Islam dalam mengenal Malaikat dan tugasnya menggunakan media posteroid melalui partisipasi dan kolaborasi antara peneliti selaku guru Pendidikan Agama Islam dengan guru di SD Negeri 25 selaku teman sejawat.

Adapun teknik pengumpulan data dilakukan dengan: (1) Observasi yaitu untuk melihat kekurangan atau kelebihan dalam proses pembelajaran secara langsung sebagai acuan pelaksanaan siklus pembelajaran selanjutnya; (2) Tes, yaitu suatu kegiatan yang dilakukan untuk mengukur keberhasilan penggunaan media posteroid dalam meningkatkan hasil belajar siswa pada mata pelajaran Pendidikan Agama Islam dalam mengenal malaikat dan tugasnya pada kelas IV yaitu dengan menggunakan tes tertulis dan lisan.

Teknik Analisis data dalam penelitian tindakan kelas ini yaitu menggunakan teknik analisis deskriptif kualitatif - kuantitatif. Analisis data secara kualitatif digunakan untuk menganalisis data kualitatif, seperti hasil observasi dan studi dokumentasi. Data kualitatif yaitu data yang berupa informasi berbentuk kalimat yang memberi gambaran tentang perilaku siswa, kemampuan pemahaman terhadap suatu mata pelajaran (kognitif), proses pembelajaran berlangsung atau kegiatan pelaksanaan, pandangan atau sikap siswa (afektif), antusiasme, motivasi belajar dan sejenisnya. Tahapan analisis data deskriptif kualitatif terdiri dari: pemaparan data, reduksi (data yang sudah ada di cek dan dicatat kembali), kategorisasi (data dipilahpilah), penafsiran dan penyimpulan.

Analisis data deskriptif kuantitatif digunakan untuk menganalisa data kuantitatif, seperti hasil tes. Data kuantitatif berupa nilai hasil belajar siswa yang didapat dengan menggunakan teknik analisis statistik deskriptif misalnya, mencari nilai rerata. Untuk mengetahui tingkat 
keberhasilan penelitian tindakan ini maka dapat dilihat dari: (1) Meningkatnya hasil belajar siswa pada mata pelajaran PAI dalam mengenal Malaikat dan tugasnya ditandai rata-rata nilai yang dicapai diatas KKM 75 sebanyak $75 \%$ dari jumlah siswa; (2) Adanya peningkatan keaktifan belajar siswa pada kategori sangat aktif dan aktif mencapai $80 \%$.

\section{HASIL DAN PEMBAHASAN PENELITIAN}

Pra siklus adalah tahapan awal yang dilakukan untuk melihat hasil belajar siswa sebelum menggunakan media pembelajaran serta melihat proses pembelajaran yan dilakukan oleh pendidik di kelas yang dapat dijadikan sebagai acuan dalam melakukan penelitian selanjutnya. Adapun gambaran awal di SD Negeri 25 Sungai Kakap adalah hasil belajar siswa pada materi Mengenal Malaikat dan Tugasnya hanya berkisar
$11,11 \%$ atau 2 orang siswa yang tuntas dalam pembelajaran pada materi Mengenal Malaikat dan Tugasnya dari 18 orang siswa. Hal ini menunjukkan bahwa masih rendahnya hasil pembelajaran siswa kelas IV SD Negeri 25 Sungai Kakap pada materi mengenal Malaikat dan Tugasnya. Berdasarkan hal tersebut, maka keinginan peneliti selaku guru agama adalah meningkatkan hasil belajar siswa dengan menggunakan media posteroid dengan harapan siswa menjadi termotivasi atau bersemangat mengikuti proses pembelajaran yang pada akhirnya akan berpengaruh pada meningkatnya hasil belajar Pendidikan Agama Islam pada materi Mengenal Malaikat dan Tugasnya. Dalam penelitian ini pembelajaran dilakukan dalam satu pra siklus dan tiga siklus sebagaimana pemaparan sebagai berikut ini. Adapun hasil belajar pra siklus dapat dilihat pada tabel dibawah ini

Tabel 1. Hasil Belajar Siswa Pra Siklus

\begin{tabular}{cccc}
\hline No & Nama & Nilai & Keterangan \\
\hline 1 & AL & 80 & Tuntas \\
\hline 2 & AB & 30 & Tidak tuntas \\
\hline 3 & BD & 40 & Tidak tuntas \\
\hline 4 & BG & 50 & Tuntas \\
\hline 5 & SD & 80 & Tidak tuntas \\
\hline 6 & MA & 50 & Tidak tuntas \\
\hline 7 & RS & 60 & Tidak tuntas \\
\hline 8 & WD & 30 & Tidak tuntas \\
\hline 9 & QW & 30 & Tidak tuntas \\
\hline 10 & ID & 60 & Tidak tuntas \\
\hline 11 & DF & 60 & Tidak tuntas \\
\hline 12 & GH & 60 & Tidak tuntas \\
\hline 13 & JK & 60 & Tidak tuntas \\
\hline 14 & JN & 70 & Tidak tuntas \\
\hline 15 & MN & 65 & Tuntas \\
\hline 16 & KO & 70 & Tuntas \\
\hline 17 & PL & 80 & 1055 \\
\hline 18 & QA & 80 & 58,61 \\
\hline & Jumlah Nilai & & $22,22 \%$ \\
\hline & Nilai Rata-Rata & & \\
\hline & Persentase Ketuntasan & & \\
\hline
\end{tabular}

Dari tabel diatas menunjukkan rata-rata hasil belajar siswa pada materi malikat dan tugasnya pada pra siklus siswa kelas IV SD Negeri 25 Sungai Kakap sebesar 58,61 dengan persentase ketuntasan sebesar 22,22\%. Hal ini menunjukkan hasil belajar yaitu rata-rata klasikal siswa belum mencapai KKM. Hal ini terjadi karena guru masih selalu menggunakan metode ceramah serta tidak menggunakan media pembelajaran yang mampu menarik dan menumbuhkan motivasi siswa. Hal ini dapat dilihat dari data bahwa persentase keaktifan mengenai aktivitas belajar siswa pra siklus dari 18 siswa didapat data sebanyak 4 orang atau $20 \%$ siswa aktif saat proses pembelajaran dilaksanakan, 4 atau $20 \%$ siswa kurang aktfi dalam pembelajaran dikelas 
serat 10 atau $60 \%$ siswa tidak aktif dikelas.

Siklus I dilaksanakan dengan tahapan: (1) Perencanaan, guru menyiapkan administrasi yang diperlukan untuk kegiatan pembelajaran siklus I yang akan dilaksanakan agar berjalan lancar, meliputi menyiapkan materi pelajaran tentang Malikat dan Tugasnya, menyiapkan RPP sesuai dengan materi yang akan disampaikan, membuat media pembelajaran Posteroid, membuat instrument penilaian; (2) Pelaksanaan, yaitu pada tahap ini peneliti selaku guru Pendidikan Agama Islam melakukan penelitian dengan berkolaborasi bersama teman sejawat sebagai observer untuk mencatat segala aktifitas yang dilakukan oleh guru sehingga dapat dilihat kelemaha-kelemahan yang dilakukan untuk dijadikan acuan dalam memperbaiki proses pembelajaran berikutnya. Adapun hasil belajar pada siklus I yaitu:

Tabel 2. Hasil Belajar Siswa Siklus I

\begin{tabular}{|c|c|c|c|}
\hline No & Nama & Nilai & Keterangan \\
\hline 1 & $\mathrm{AL}$ & 30 & Tidak Tuntas \\
\hline 2 & $\mathrm{AB}$ & 50 & Tidak tuntas \\
\hline 3 & $\mathrm{BD}$ & 40 & Tidak tuntas \\
\hline 4 & BG & 75 & Tuntas \\
\hline 5 & $\mathrm{SD}$ & 30 & Tidak tuntas \\
\hline 6 & MA & 60 & Tidak tuntas \\
\hline 7 & RS & 75 & Tuntas \\
\hline 8 & WD & 75 & Tuntas \\
\hline 9 & QW & 50 & Tidak tuntas \\
\hline 10 & ID & 75 & Tuntas \\
\hline 11 & DF & 75 & Tuntas \\
\hline 12 & GH & 75 & Tuntas \\
\hline 13 & JK & 60 & Tidak tuntas \\
\hline 14 & $\mathrm{JN}$ & 50 & Tidak tuntas \\
\hline 15 & MN & 50 & Tidak tuntas \\
\hline 16 & $\mathrm{KO}$ & 70 & Tidak tuntas \\
\hline 17 & PL & 80 & Tuntas \\
\hline 18 & QA & 80 & Tuntas \\
\hline \multicolumn{2}{|c|}{ Jumlah Nilai } & \multicolumn{2}{|c|}{1100} \\
\hline \multicolumn{2}{|c|}{ Nilai Rata-Rata } & \multicolumn{2}{|c|}{61,11} \\
\hline \multicolumn{2}{|c|}{ Persentase Ketuntasan } & \multicolumn{2}{|c|}{$44,44 \%$} \\
\hline
\end{tabular}

Dari data pelaksanaan siklus I menunjukkan bahwa proses pembelajaran dengan menggunakan media posteroid pada siswa pada pelajaran Pendidikan Agama Islam materi Mengenal Malaikat dan Tugasnya mengalami peningkatan dibandingkan dengan hasil belajar pada pra siklus yang masih bersifat konvensional atau menggunakan metode cermah. Dari hasil tes siklus I diketahui bahwa peserta didik yang tuntas dari KKM yang ditentukan 7,5 sebanyak 8 atau anak $(44,44 \%)$ dari 18 anak dengan nilai tertinggi: 80 dan terendah: 30 dengan nilai ratarata: 55; (3) Pengamatan yaitu melihat aktifitas belajar siswa dikelas menunjukkan adanya peningkatan dalam proses pembelajaran. Hal ini dapat diketahui dari hasil observasi yaitu siswa yang terlibat aktif dalam proses belajar mengajar hanya 8 orang $(44,44 \%)$ dan yang kurang aktif berjumlah 2 orang $(22,22 \%)$ dan yang tidak aktif berjumlah 8 orang $(44,44 \%)$ berarti terdapat peningkatan keaktifan dalam proses belajar mengajar pada saat siklus pertama dengan menggunakan media posteroid; (4) Refleksi, yaitu melihat kekurangan dalam proses pembelajaran dijadikan sebagai acuan pada siklus selanjutnya. Kemudian dilaksanakan siklus ke dua dengan tahapan yang sama yaitu: (1) Perencanaan, yaitu melakukan kegiatan 
penyiapan siklus II; (2) Pelaksanaan, yaitu dengan melakukan pembelajaran yang telah dirancang sebelumnya hingga dilakukanlah tes akhir. Adapun hasil belajar siklus II yaitu:

Tabel 3. Hasil Belajar Siswa Siklus II

\begin{tabular}{cccc}
\hline No & Nama & Nilai & Keterangan \\
\hline 1 & AL & 60 & TidakTuntas \\
\hline 2 & AB & 85 & Tidak Tuntas \\
\hline 3 & BD & 80 & Tuntas \\
\hline 4 & BG & 80 & Tuntas \\
\hline 5 & SD & 45 & Tidak tuntas \\
\hline 6 & MA & 80 & Tuntas \\
\hline 7 & RS & 85 & Tuntas \\
\hline 8 & WD & 85 & Tidak tuntas \\
\hline 9 & QW & 60 & Tuntas \\
\hline 10 & ID & 85 & Tuntas \\
\hline 11 & DF & 80 & Tidak tuntas \\
\hline 12 & GH & 80 & Tidak Tuntas \\
\hline 13 & JK & 60 & Tidak Tuntas \\
\hline 14 & JN & 70 & Tidak Tuntas \\
\hline 15 & MN & 70 & Tuntas \\
\hline 16 & KO & 70 & Tidak Tuntas \\
\hline 17 & PL & 70 & 1305 \\
\hline 18 & QA & 60 & 72,5 \\
\hline & Jumlah Nilai & & $50 \%$ \\
\hline & Nilai Rata-Rata & &
\end{tabular}

Dari data pelaksanaan siklus II menunjukkan bahwa proses pembelajaran dengan menggunakan media posteroid pada siswa pada materi mengenal malaikat dan tugastugasnya mengalami peningkatan dibandingkan dengan hasil belajar sebelum menggunakan media posteroid. Dari hasil tes siklus II diketahui bahwa persentase ketuntasan mencapai $50 \%$ dengan nilai rata-rata kelas 72,5 . Nilai tertinggi 85 dan nilai terendah 45; (3) Observasi yaitu melihat aktifitas pada siklus II yang menunjukkan setelah digunakan media posteroid pada materi mengenal Malaikat dan Tugasnya dengan persentase ketuntasan 50\% dengan jumlah siswa 9 dan yang tidak tuntas sebanyak 9 orang dengan persentasi5 $0 \%$ dan nilai tersebut dapat dikategorikan sedang serta secara klasikal telah mengalami peningkatan yang lebih baik dari pada pra siklus dan siklus I, namun seara klasikal hasil belajar belum mencapai KKM; (4) Refleksi dilakukan untuk melihat hal-hal yang masih kurang dalam pembelajaran untuk memperbaiki siklus III.

Siklus III dilakukan peneliti dengan menyusun beberapa kegiatan berupa: (1) perencanan, dengan menyiapkan adminitrasi yang diperlukan serta media pembelajaran Posteroid; (2) Pelaksanaan, dengan melakukan kegiatan sesuai perencanaan untuk mendapatkan hasil belajar yang maksimal. Adapun hasil belajar siklus III yaitu:

Tabel 4. Hasil Belajar Siswa Siklus III

\begin{tabular}{cccc}
\hline No & Nama & Nilai & Keterangan \\
\hline 1 & AL & 100 & Tuntas \\
\hline 2 & AB & 100 & Tuntas \\
\hline 3 & BD & 100 & Tuntas \\
\hline 4 & BG & 100 & Tuntas \\
\hline
\end{tabular}




\begin{tabular}{|c|c|c|c|}
\hline 5 & SD & 95 & Tuntas \\
\hline 6 & MA & 90 & Tuntas \\
\hline 7 & $\mathrm{RS}$ & 100 & Tuntas \\
\hline 8 & WD & 100 & Tuntas \\
\hline 9 & QW & 80 & Tuntas \\
\hline 10 & ID & 90 & Tuntas \\
\hline 11 & DF & 100 & Tuntas \\
\hline 12 & $\mathrm{GH}$ & 100 & Tuntas \\
\hline 13 & $\mathrm{JK}$ & 75 & Tuntas \\
\hline 14 & $\mathrm{JN}$ & 100 & Tuntas \\
\hline 15 & $\mathrm{MN}$ & 90 & Tuntas \\
\hline 16 & $\mathrm{KO}$ & 100 & Tuntas \\
\hline 17 & PL & 80 & Tuntas \\
\hline 18 & QA & 100 & Tuntas \\
\hline Jum & & \multicolumn{2}{|c|}{1700} \\
\hline Nila & & \multicolumn{2}{|c|}{94,44} \\
\hline Per: & & \multicolumn{2}{|c|}{$100 \%$} \\
\hline
\end{tabular}

Dari data pelaksanaan siklus III menunjukkan bahwa proses pembelajaran dengan penggunaan media posteroid pada siswa materi mengenal malaikat dan tugas-tugasnya mengalami peningkatan dibandingkan dengan hasil belajar sebelum penggunaaan media posteroid. Dari hasil tes siklus III diketahui bahwa siswa yang tuntas dari KKM yang ditentukan 7,5 sebanyak 18 anak (100\%) dari 18 anak dengan nilai tertinggi: 100 dan terendah: 75 dengan nilai rata-rata: 94,44. Data ini menunjukkan bahwa penggunaan media posteroid pada materi Mengenal Malaikat dan Tugasnya sangat baik digunakan dalam proses pembelajaran,dapat diperhatikan data pra siklus nilai ketuntasan hanya 4 orang siswa $(22,22 \%)$, dan meningkat 8 orang siswa $(44,44 \%)$ pada siklus I, dan pada siklus II meningkat 9 orang siswa $50 \%$, dan meningkat lagi pada siklus III dimana18 orang siswa (100\%), jadi pada siklus III semua siswa tuntas dalam pembelajaran; (3) Pengamatan yaitu dengan melihat aktifitas proses pembelajaran pada siklus III yang menunjukkan bahwa penggunaan media posteroid pada materi mengenal malaikat dan tugas-tugasnya pelaksanaannya dapat berjalan sesuai dengan Rencana Pelaksanaan Pembelajaran (RPP), penyampaian materi yang dilakukan guru telah sesuia, smengikuti pembelajaran dengan tertib, melakukan permainan dengan media posteroid dengan semangat, dan semua kegiatan dalam pantauan guru, siswa berperan aktif dari siklus sebelumnya, pelaksanaan pembelajaran menjadi lebih terarah dan menyenangkan, siswa mengerjakan dengan baik tugas yang diberikan oleh guru hal itu dapat dilihat dari hasil tes pada siklus III siswa yang tuntas dari KKM yang ditentukan mencapai 100\%; (4) Refleksi pada kegiatan siklus III yaitu pembelajaran telah dilaksanakan sesuai dengan perencanaan, pembelajaran berpusat pada siswa dan hasil belajar telah mencapai KKM sehingga tidak perlu dilakukan siklus berikutnya.

\section{SIMPULAN DAN SARAN \\ Simpulan}

Penelitian tindakan kelas di SD Negeri 25 Sungai Kakap dilaksanakan dengan menggunakan media Posteroid, yang dibuat oleh guru dengan maksud meningkatkan hasil belajar pada pelajaran Pendidikan Agama Islam Materi Mengenal Malaikat menunjukkan: (1) Penggunaan media Posteroid mapu meningkatkan hasil belajar siswa. Dengan media ini, siswa menjadi lebih tertarik mengikuti proses pembelajaran yang dilaksanakan serta aktif di kelas. Media ini mempermudah siswa memahami materi yang disampaikan. Penggunaan media Posteroid dalam pembelajaran menjadikan siswa tidak bosan di kelas karena pelaksanaan pembelajaran menjadi sangat menyenangkan bagis siswa SD; (2) Nilai rata-rata siswa SD Negeri 25 Sungai Kakap sebelum diterapkan media Posteroid adalah 55.61, kemudian diterapkan media Posteroid sehingga pada siklus I terjadi peningkatan nilai rat-rata menjadi 61.11, kemudian dilakukan refleksi terhadap proses pembelajaran sebagai acuan melakukan kegiatan 
siklus II sehingga pada siklus II meningkat menjadi 72,5. Karena masih belum mencapai ketuntasan maka dilakukan siklus III dan pada siklus ini rata-rata hasil belajar telah mencapai ketuntasan yaitu 94.44; (3) Penggunaan media Posteroid mampu meningkatkan hasil belajar siswa. Adapun jumlah siswa yang mencapai ketuntasan pada siklus I sebanyak 8 orang atau $44,44 \%$, pada siklus II sebanyak 9 atau $50 \%$ siswa dan pada siklus III sebanyak 18 atau $100 \%$ siswa telah mencapai ketuntasan.

\section{Saran}

Proses pembelajaran amatlah penting bagi siswa. Oleh karena itu sebagai pendidik hendaknya mampu menciptakan proses pembelajaran yang bermakna bagi siswa sehingga akan tersimpan dalam memori atau ingatan jangka panjang siswa dan akhirnya akan berpengaruh pada hasil belajar siswa. Agar hal ini tercapai, maka: (1) Pendidik mampu menciptakan proses pembelajaran yang sesuai dengan karakteristik siswa SD yang mampu menumbuhkan semangat atau motivasi siswa; (2) Pendidik harus mampu memanfaatkan kemajuan teknologi sehingga mampu menciptakan berbagai media pembelajaran menarik yang dapat digunakan dalam proses pembelajaran; (3) Pendidik harus melakukan refleksi terhadap cara mengajar dengan cara berkolaborasi sehingga dapat mengetahui kekurangan yang dilakukan dalam pembelajaran; (4) selalu membantu dan memotivasi peserta didik untuk terbiasa membuat variasi dan inovasi dalam pembelajaran, agar paserta didik tidak bosan dalam pembelajaran, dan timbul rasa senang serta percaya diri, juga tidak malu dan takut dalam berinteraksi dengan sesama peserta didik.

\section{DAFTAR PUSTAKA}

Agus Taufik. 2010. Pendidikan Anak di SD. Tangerang Selatan, Universitas Terbuka.

Arikunto. 2009. Penelitian Tindakan Kelas. Jakarta: Bumi Akasara.

Daryanto. 2018. Penelitian Tindakan Kelas dan Penelitian Tindakan Sekolah.Jogjakarta,Gava Media.

Dimyanti. 1999. Belajar dan Pembelajaran, Jakarta : Rineka Cipta.

Djamarah, Syaiful Bahri. 2000. Strategi Belajar Mengajar, Jakarta : Rineka Cipta.

Djamarah, Syaiful Bahri. 2006.Guru dan Anak Didik dalam Interaksi Edukatif, Jakarta: Rineka Cipta.

Ramayulis. 2008. Metodologi Pendidikan Agama Islam. Jakarta: Kalam Mulia.

Sadiman,Arief. 2010. Media Pendidikan, Jakarta: Rajawali Pres.

Yatim. 2006. Pengembangan Kurikulum dan Seputar Kurikulum Tingkat Satuan Pendidikan (KTSP), IKAPI : Universiti Press 